\title{
Artur Pasko
}

\section{Kulisy przyjęcia ZSRR do Międzynarodowego Komitetu Olimpijskiego}

\begin{abstract}
Abstrakt: Od 1951 r. Związek Radziecki jest członkiem Międzynarodowego Komitetu Olimpijskiego. Przynależność do tej organizacji uprawniała sportowców radzieckich do udziału w igrzyskach olimpijskich. Interesujące jest zatem poznanie okoliczności wstępowania ZSRR do MKOl oraz uzyskanie odpowiedzi na pytania: Jakie stanowisko prezentował prezydent Johannes Sigfrid Edström oraz członkowie MKOl w tej sprawie? Jaka była pozycja ZSRR w procesie wstępowania do MKOl? Podstawę źródłową pracy stanowią materiały znajdujące się w Archiwum MKOl w Lozannie.
\end{abstract}

Słow a kluc z ow e: Johannes Sigfrid Edström, ZSRR, MKOl, Konstantin A. Adrianow.

Abstract: The Soviet Union has been a member of the International Olympic Committee since 1951. This membership entitled Soviets sportsmen to participate in the Olympic Games. It is, therefore, interesting to explore the circumstances of the Soviet Union's access to the IOC to answer the following questions: What was the stance of President Johannes Sigfrid Edström and the IOC members on this matter? What was the position of the USSR within the process of accession to the IOC? The analysis is based on the source material kept in the Archives of the International Olympic Committee in Lausanne, Switzerland.

Key w or d s: Johannes Sigfrid Edström, USSR, IOC, Konstantin A. Andrianov.

Często zapominamy, że idea twórcy nowożytnego ruchu olimpijskiego, barona Pierre'a de Coubertina, miała charakter pokojowy. Francuz był świadkiem wojny francusko-pruskiej toczonej w latach 1870-1871 i jej skutków

\footnotetext{
${ }^{1}$ Szerzej zob. A. Pasko, Baron Pierre de Coubertin - wizjoner i idealista, w: Ruch olimpijski $w$ teorii i praktyce, red. J. Eider, Szczecin 2015, s. 7 i n.
} 
Bardzo prawdopodobne, że konsekwencje tamtych doświadczeń stanowiły narodziny idealistycznych założeń, zgodnie z którymi honorowa rywalizacja sportowa miała przyczynić się do „zaniku wojen”. To przecież w Odzie do sportu Coubertin pisał: „O Sporcie! Ty jesteś Pokój! Ty ustanawiasz przyjacielskie zwiazki między ludami [...]"3. Nazbyt szybko okazało się, że były to złudne nadzieje. Wszak niespełna 20 lat po zorganizowaniu pierwszych nowożytnych igrzysk olimpijskich i 2 lata po zdobyciu przez Coubertina medalu w olimpijskim konkursie sztuki w Sztokholmie za wspomniana Ode do sportu wybuchła I wojna światowa. W pierwszych latach okresu międzywojennego w tej - jak się dzisiaj określa - wielkiej rodzinie olimpijskiej zabrakło wielu państw. Poza ruchem olimpijskim i jego strukturami znalazły się więc kraje odpowiedzialne za wybuch I wojny światowej oraz Związek Radziecki ${ }^{4}$.

Wybuch II wojny światowej po raz kolejny potwierdził, że nowożytny olimpizm, pomimo wielu walorów, nie ma tak wielkiej siły sprawczej, by wpłynąc na utrzymanie pokoju. Po zakończeniu światowego konfliktu, wbrew rosnacemu napięciu zimnowojennemu, do udziału w igrzyskach olimpijskich w 1948 r. w Londynie zaproszony został Związek Radziecki. Wtedy przez krótki czas można było łudzić się, że idea olimpijska zatriumfuje nad polityka. Jeżeli jednak głębiej przeanalizujemy ówczesną sytuację, dostrzeżemy, że włączenie ZSRR do ruchu olimpijskiego niosło dla niego ogromne zagrożenie. Doskonale zdawali też sobie z tego sprawę włodarze Międzynarodowego Komitetu Olimpijskiego (MKOl) na czele z ówczesnym prezydentem tej organizacji, Johannesem Sigfridem Edströmem. 12 XI 1947 r. członek Komitetu Wykonawczego MKOl, Colonel Pieter Wilhelmus Scharroo, ostrzegał Edströma. Holender twierdził, że rząd radziecki wykorzystywał sport do wzmocnienia siły militarnej i ekonomicznej kraju. Ponadto, jego zdaniem, jakiekolwiek federacje sportowe i komitet olimpijski powołane w tym kraju, czy członek MKOl wywodzący się z ZSRR, byliby w pełni zależni od rządu radzieckiego ${ }^{5}$. Inny działacz MKOl, późniejszy prezydent tej organizacji, Avery Brundage z USA także doskonale zdawał sobie sprawę $\mathrm{z}$ ówczesnych realiów panujących nie tylko w ZSRR, ale też w pozostałych krajach Europy Środkowo-Wschodniej. Bowiem twierdził on: „Jeśli uwzględnimy podstawowe zasady olimpijskie i podporządkujemy się regulacjom

\footnotetext{
${ }^{2}$ Końcowe stowa przemówienia Pierre'a de Coubertina wygtoszonego na jubileuszowej sesji Unii Francuskich Towarzystw Sportów Atletycznych (USFA) na Sorbonie w dniu 25 listopada 1892 r., w: P. de Coubertin, Przemówienia. Pisma różne i listy, wstęp, wybór i oprac. G. Młodzikowski, przy współpr. K. Hądzelka, Warszawa 1994, s. 14.

${ }^{3}$ P. de Coubertin, Oda do sportu, tłum. J. Sadowska, Warszawa 1996, s. 14.

${ }^{4}$ Szerzej zob. D. Miller, Historia igrzysk olimpijskich i MKOl. Od Aten do Pekinu 1894-2008, Poznań 2008, s. 79 i n.

${ }^{5}$ V. Peppard, J. Riordan, Playing Politics. Soviet Sport Diplomacy to 1992, Greenwich-London 1993, s. 65.
} 
i przepisom w żaden sposób nie możemy uznać jakiegokolwiek komunistycznego komitetu olimpijskiego"'.

W tej sytuacji nasuwa się pytanie, dlaczego wobec takich zagrożeń liderzy MKOl skierowali do Rosjan zaproszenie do udziału w igrzyskach? Czyżby sądzili, że nie zaakceptuja oni reguł ruchu olimpijskiego i odrzuca zaproszenie? Jaka pozycję zajmował ZSRR w tym procesie wstępowania do MKOl? ${ }^{7}$ Wobec dotychczasowej absencji Rosjan na igrzyskach można było przypuszczać, że po II wojnie światowej zostali oni skazani na łaskę i niełaskę władz ruchu olimpijskiego. A może jednak Rosjanie dysponowali argumentami, które wzmacniały ich pozycję $\mathrm{w}$ staraniach o wejście do MKOl? Wobec niedostatku dokumentów niezwykle trudno uzyskać jednoznaczne odpowiedzi na postawione pytania. Sa jednak przesłanki pozwalające na wyciągnięcie wniosków.

W Archiwum MKOl w Lozannie zachował się list ówczesnego prezydenta MKOl, Edströma, napisany 6 III 1947 r. i przetłumaczony na język rosyjski. Pismo było adresowane do przewodniczącego Wszechzwiązkowego Komitetu Kultury Fizycznej i Sportu ZSRR Nikołaja Romanowa. Prezydent MKOl prosił w nim Rosjanina o przysługę. Edströmowi zależało na uzyskaniu informacji o losie przyjaciela, członka MKOl, Karla Rittera von Halta. Według wiedzy Szweda Halt miał dostać się do niewoli radzieckiej, a następnie trafić do obozu w Buchenwaldzie. Prezydent MKOl zwracał się do Rosjan z prośbą o informacje na temat terminu ewentualnego powrotu Niemca do domu lub - w przypadku jego śmierci - określenia miejsca pochówku․ Niestety, nie zachowała się odpowiedź Romanowa na pismo Edströma. Nie wiemy nawet, czy takowa nadeszła. Wiadomo jednak, że Halt wrócił do domu na początku 1950 r. Informacja taka ukazała się 26 I 1950 r. w „Der Spiegel”9. Karl Ritter von Halt był przez kilka lat więziony w radzieckim obozie jenieckim. W $1947 \mathrm{r}$. do jego rodziny dotarła wiadomość, że nie żyje. Prawdopodobnie właśnie wtedy Edström napisał swój list do Romanowa. Jednakże możemy przypuszczać, że - jak to określił David Miller - Rosjanie zwolnili z więzienia Halta, kierując się „względami praktycznymi”" ${ }^{10}$. Zapewne miały one związek z ich ambicjami dołączenia do MKOl.

${ }^{6}$ Cyt. za: ibidem, s. 67. Tekst w oryginale brzmiał następująco: „If we conform to fundamental Olympic principles and follow our rules and regulations we cannot possibly recognize any Communist Olympic committee”. Zob. też: A. Pasko, Spoteczno-polityczne aspekty sportu $w$ ZSRR $i$ krajach bloku socjalistycznego do 1989 r., „Prace Naukowe Akademii im. Jana Długosza w Częstochowie. Kultura Fizyczna” 2011, z. 10, s. 115 i n.

${ }^{7}$ Dzisiaj MKOl jest potężna, pod względem liczby członków i budżetu, organizacją. Wszak zrzesza 206 narodowych komitetów olimpijskich. Zob. https://www.olympic.org/national-olympic-committees?q=ProtocolOrderFilter (dostęp: 1 XII 2017).

8 Archiwum Międzynarodowego Komitetu Olimpijskiego w Lozannie (dalej: AMKOl), A-P04/003, Pismo prezydenta MKOl, Sigfrida Edströma do przewodniczącego Wszechzwiązkowego Komitetu Kultury Fizycznej i Sportu ZSRR, Nikołaja Romanowa z dnia 6 III 1947 r., k. nlb.

${ }_{9}$ Karl Ritter von Halt, „Der Spiegel”, 26 I 1950, Nr. 4, http://www.spiegel.de/spiegel/ print/d-44446298.html (dostęp: 25 IX 2017).

${ }^{10}$ D. Miller, op. cit., s. 150. 
W kolejnym liście do Romanowa, wysłanym pod koniec maja 1947 r., Edström odnosił się do prób przystapienia ZSRR do międzynarodowych organizacji i federacji sportowych. W treści tego pisma odnajdujemy swoiste instrukcje, jakich udzielał Rosjanom. Informował więc, że w Moskwie powinien powstać narodowy komitet olimpijski uznany przez MKOl. Prezydent MKOl przesłał także spis zasad obowiąujących w ruchu olimpijskim, które należało zaakceptować, by móc uczestniczyć w igrzyskach ${ }^{11}$. Szwed uważnie obserwował postępy Rosjan w zakresie ich włączania się do międzynarodowych struktur sportowych. Wszak pod koniec 1947 r., w kolejnym piśmie do Romanowa, prezydent MKOl docenił fakt przyjęcia radzieckich organizacji do międzynarodowych federacji sportowych, na czele z Międzynarodowym Stowarzyszeniem Federacji Lekkoatletycznych (IAAF). Edström nieoczekiwanie poinformował Rosjan, że nie musieli tworzyć nowej organizacji zarządzajacej sportem olimpijskim. Polecił jedynie, by przekazali mu wiadomość, że taka organizacja istniała. Oczekiwał też, że oficjalnie zostanie podany adres instytucji i nazwisko szefa oraz sekretarza tej organizacji. Po spełnieniu tych warunków wszyscy radzieccy sportowcy mieli uzyskać prawo startu w igrzyskach olimpijskich, począwszy od zimowych igrzysk w Sankt Moritz i igrzysk olimpijskich w Londynie w 1948 r. ${ }^{12}$

Edström wykazywał spore zaangażowanie w sprawę przyjęcia ZSRR do MKOl. Obawiał się jednak, że ten pomysł nie zyska poparcia Amerykanów, członków tej organizacji ${ }^{13}$. Prezydent MKOl poczuwał się do autentycznej odpowiedzialności za realizację dzieła zapoczątkowanego przez barona Pierre'a de Coubertina ${ }^{14}$. Zależało mu na szerzeniu idei olimpijskiej na jałowym gruncie Kraju Rad. Z jego korespondencji z kanclerzem MKOl, Ottonem Mayerem, wiemy, że Edström chciał uniknąć podziału świata sportu na Wschód i Zachód ${ }^{15}$. Tymczasem działacze MKOl na czele z prezydentem tej organizacji musieli zdawać sobie sprawę z konsekwencji udziału ZSRR w ruchu olimpijskim. Wcześniej Edström znany był z konserwatywnych poglądów, wielokrotnie też podważał amatorski status sportowców radzieckich. Wyłania nam się zatem obraz prezydenta MKOl, który świadomie rezygnował z własnych uprzedzeń do ZSRR dla dobra olimpizmu i jego jedności. Ale czy rzeczywiście temu służyły ustępstwa? Prezydent MKOl powinien zdawać sobie sprawę, że przyjęcie ZSRR do tej organizacji zmieni dotychczasowy porządek w niej

\footnotetext{
${ }^{11}$ AMKOl, A-P04/003, Pismo prezydenta MKOl, Sigfrida Edströma do przewodniczącego Wszechzwiązkowego Komitetu Kultury Fizycznej i Sportu ZSRR, Nikołaja Romanowa z dnia 25 V 1947 r., k. nlb.

${ }^{12}$ Ibidem, Pismo prezydenta MKOl, Sigfrida Edströma do przewodniczącego Wszechzwiązkowego Komitetu Kultury Fizycznej i Sportu ZSRR, Nikołaja Romanowa z dnia 15 XII 1947 r., k. nlb.

${ }^{13}$ D. Miller, op. cit., s. 150.

14 AMKOl, P04/006, Pismo J.S. Edströma do Otto Mayera z dnia 25 IV 1951 r., k. nlb.

${ }^{15}$ Ibidem, Pismo J.S. Edströma do Otto Mayera z dnia 24 IV 1951 r., k. nlb.
} 
panujący ${ }^{16}$. Czyżby Edström naiwnie wierzył, że igrzyska i idea olimpijska będa służyły nie tylko zacieraniu podziałów w sporcie, ale też w spolaryzowanym świecie? Nie możemy wykluczyć potwierdzenia takich oczekiwań i nadziei Edströma. Zastanawiająca jest jednak inna kwestia. Dlaczego 45. Sesja MKOl, na której decydowano o włączeniu do struktur międzynarodowego ruchu olimpijskiego ZSRR, zorganizowana została w Wiedniu? Przecież stolica Austrii była wówczas podzielona na cztery sektory. Jeden z nich znajdował się pod okupacją radziecka, zaś dzielnica środkowa miasta - pod wspólną okupacja radziecka, amerykańska, brytyjska i francuska ${ }^{17}$. Niestety, nie mamy pewności, w jakiej części miasta odbyła się sesja MKOl. Nie ulega jednak watpliwości, że organizowanie jej wówczas w Wiedniu znacząco wzmacniało pozycję Rosjan w zabiegach o przyjęcie do MKOl. Wyraźnie widać, że prezydentowi MKOl zabrakło wyobraźni politycznej. Owe ustępstwa wobec Rosjan mogły być przez nich traktowane jako oznaka słabości, w perspektywie mogły też zachęcać ich do wzmacniania swojej pozycji w łonie MKOl. Szybko okazało się też, że ZSRR nie był skłonny do ułatwiania życia członkom MKOl, nie zapewnił im bezpieczeństwa przy wjeździe do miasta. Otóż na początku 1951 r. Mayer informował prezydenta MKOl, że członkowie tej organizacji obawiali się przyjazdu do Wiednia pociagiem ze względu na radzieckie kontrole pomiędzy Innsbruckiem i Wiedniem. Dlatego też, by ich uniknać, Mayer zdecydował się na podróż samolotem. Wybieranie tego środka lokomocji doradzał również innym członkom $\mathrm{MKOl}^{18}$.

17 IV 1951 r. Edström w korespondencji z Mayerem przyznał się, że decyzja o organizacji sesji w Wiedniu była poważnym błędem, bowiem - jak to określił - Rosjanie sprawowali największą kontrolę policyjną nad miastem. Stwierdził też, że wcześniej nie przewidział wielu problemów, jakie pojawiły się w związku z organizacją tej sesji i chociaż - jak uważał - nie był lubiany przez Rosjan, to wybierał się do Wiednia, bo wierzył, że rząd austriacki go ochroni ${ }^{19}$. Ta opinia Edströma potwierdziła, że był on tylko działaczem sportowym, tymczasem w ówczesnych warunkach musiał być też politykiem. Opinia ta świadczyła również o zupełnym niezrozumieniu ówczesnej sytuacji politycznej. Wszak możliwości ówczesnego rządu austriackiego ochrony przed władzami państwa okupującego były raczej mocno ograniczone. Zdawali sobie z tego sprawę niemieccy członkowie MKOl: Adolf von Mecklenburg oraz Karl Ritter von Halt, którzy twierdzili, że Rosjanie zamierzali ich aresztować ${ }^{20}$.

\footnotetext{
${ }^{16}$ M. Słoniewski, Wpływ przewodniczacych Międzynarodowego Komitetu Olimpijskiego na przemiany $w$ międzynarodowym ruchu olimpijskim po II wojnie światowej, „Prace Naukowe Akademii im. Jana Długosza w Częstochowie. Kultura Fizyczna” 2017, t. XVI, nr 1 , s. 52 .

${ }_{17}$ H. Wereszycki, Historia Austrii, Wrocław-Warszawa-Kraków-Gdańsk-Łódź 1986, s. 303.

18 AMKOl, P04/006, Pismo Otto Mayera do S. Edströma z dnia 31 I 1951 r., k. nlb.

19 Ibidem, Pismo S. Edströma do Otto Mayera z dnia 17 IV 1951 r., k. nlb.

${ }^{20}$ Ibidem.
} 
W rezultacie obaj Niemcy nie pojawili się na wiedeńskiej sesji. Członkom MKOl wybierającym się do Wiednia towarzyszyła więc atmosfera strachu. Te obawy mogły mieć znaczenie podczas obrad.

Rosjanie podjęli staranne działania, które miały im zapewnić przystąpienie do MKOl. W sierpniu 1950 r. utworzyli Komitet Olimpijski ZSRR ${ }^{21}$. Natomiast 23 IV 1951 r. wysłali do Lozanny telegram w języku angielskim $\mathrm{z}$ informacją o utworzeniu tego komitetu. Kierował nim Konstantin Adrianow. Był on jednocześnie kandydatem na członka MKOl. Rosjanie oficjalnie zaaprobowali też zasady ruchu olimpijskiego ${ }^{22}$.

45. Sesja MKOl w Wiedniu została zorganizowana w dniach 5-9 V $1951 \mathrm{r}$. Pierwszego dnia, na początku obrad, Edström przedstawił wniosek o przyjęcie Komitetu Olimpijskiego ZSRR do MKOl. Na posiedzeniu obecny był także Adrianow, chociaż nie należał jeszcze do $\mathrm{MKOl}^{23}$. To musiało mieć wpływ na postawy osób pochodzących z krajów zależnych od ZSRR. Potwierdzenie tego odnajdujemy w protokole obrad. Najpierw wypowiedział się członek MKOl z Finlandii - Erik von Frenckell, a chwilę później z Polski - Jerzy Loth. Obaj panowie lakonicznie, lecz zdecydowanie poparli kandydaturę ZSRR. Pomijając ich prywatne opinie, oficjalnie zaprezentowane stanowiska nie mogły być inne. Przecież gdyby prof. Loth wypowiedział się przeciwko kandydaturze ZSRR, nie miałby po co wracać do kraju. Natomiast gdyby uczynił tak członek MKOl z Finlandii, to niewattpliwie rozdrażniłby wielkiego sassiada. Tymczasem nie takie były cele Finlandii, która mimo nieodległych, trudnych doświadczeń z ZSRR utrzymała suwerenność kraju. Władze neutralnej Finlandii próbowały więc prowadzić taką politykę zagraniczna, która nie naruszałaby interesów ZSRR $^{24}$. Odważniej wypowiedział się natomiast książę Axel z Danii. Stwierdził on, że sprawa przyjęcia ZSRR do MKOl powinna być omawiana bez obecności przedstawiciela Związku Radzieckiego. Pewne wątpliwości przedstawił Szwajcar, brat wspomnianego wcześniej Ottona Mayera, Albert. Zauważył on, że nieznane im są szczegóły dotyczące funkcjonowania sportu w ZSRR ani też ich koncepcja amatorstwa w sporcie. Mimo to A. Mayer w swojej oficjalnej wypowiedzi nie sprzeciwiał się kandydaturze ZSRR ${ }^{25}$. Wbrew wspomnianym wcześniej obawom Edströma większych zastrzeżeń do kandydatury ZSRR nie miał amerykański członek MKOl, Brundage ${ }^{26}$. Natomiast Ahmed E.H. Jaffar z Pakistanu stwierdził, że nie sprzeciwia się działaniom sprzyjajacym

\footnotetext{
${ }^{21}$ M. Słoniewski, op. cit. s. 52.

22 AMKOl, P04/006, Pismo Otto Mayera do S. Edströma z dnia 24 IV 1951 r., k. nlb.

${ }^{23}$ AMKOl, Liste de présence, w: Comité International Olympique. Procès-Verbal. $45^{M E}$ Session de Vienne 1951, s. 3.

${ }^{24}$ N. Davies, Europa. Rozprawa historyka z historia, tłum. E. Tabakowska, Kraków 2001, s. 1159.

25 AMKOl, Séance du Lundi 7 Mai 1951, w: Comité International Olympique. Procès-Verbal. $45^{M E}$ Session de Vienne $1951 \ldots$, s. 9 i n.

${ }^{26}$ Ibidem, s. 10.
} 
brataniu się młodzieży całego świata, ale jego zdaniem w tym wypadku nie można było działać pospiesznie. Należało dokładniej poznać realia funkcjonowania sportu w ZSRR. Zaskoczeniem był fakt, że podobne stanowisko zaprezentował Edström. Być może prezydent MKOl zorientował się, że jego wcześniejsze założenia stanowiły utopię. Wszak w 1951 r. miał wystarczająco dużo dowodów potwierdzajacych prawdziwy, polityczny charakter działań ZSRR. Jego zdaniem rozpatrując kandydaturę ZSRR, nie należało wykazywać pośpiechu, zwłaszcza że - jak stwierdził - Rosjanie nie dostarczyli do MKOl statutu Komitetu Olimpijskiego ZSRR. Tymczasem de facto obrońca ZSRR okazał się lord Burghley z Wielkiej Brytanii, który skonstatował, że dotychczas w podobnych sytuacjach od przedstawicieli narodowych komitetów olimpijskich z państw kandydujących do MKOl nie żądano statutu. Stwierdził więc, że wymuszanie tego dokumentu od Rosjan nie było zasadne, wystarczyło jedynie uzyskać potwierdzenie akceptacji reguł ruchu olimpijskiego. Stanowisko to poparł dr Joseph Gruss z Czechosłowacji. Trudno jednak było oczekiwać innej postawy od obywatela państwa, które znajdowało się de facto pod radziecka kontrola. W tym wypadku sojusznikiem Rosjan był także Francuz François Piétri, który okazał entuzjazm wynikający z perspektywy włączenia do ruchu olimpijskiego milionów nowych sportowców. Zdecydowanie poparł on starania Rosjan o przystapienie do MKOl. Także hrabia Thaon di Revel z Włoch oraz Angelo Bolanaki z Grecji domagali się uznania wniosku złożonego przez Rosjan i przyjęcie ich do MKOl. Włoch stwierdził nawet, że przystapienie ZSRR do ruchu olimpijskiego należałoby potraktować jako sukces $\mathrm{MKOl}^{27}$.

Po dyskusji prezydent MKOl Edström zaproponował glosowanie w sprawie uznania Komitetu Olimpijskiego ZSRR. Ostatecznie 31 osób wpisało „tak”, zaś 3 wstrzymały się od głosu. Wobec braku przeciwnych głosów wynik był bardzo korzystny dla Związku Radzieckiego.

Tego samego dnia odbyło się tajne głosowanie w sprawie kandydatury na członka MKOl Adrianowa, oficera i byłego sportowca. Jako jeden z pierwszych swoją opinię o kandydacie przedstawił Ferenc Mező. Ponieważ pochodził z Węgier, a więc z państwa znajdującego się w radzieckiej strefie wpływów, jej brzmienie było łatwe do przewidzenia - bez zastrzeżeń poparł on kandydata. Warto zauważyć, że w prywatnej korespondencji z prezydentem i sekretarzem MKOl Mezö był raczej niechętnie nastawiony do ZSRR i nowego porządku politycznego, jaki zapanował m.in. na Węgrzech ${ }^{28}$. W odniesieniu do kandydatury Adrianowa watpliwości przedstawił pochodzący z Grecji Bolanaki. Generalnie - jak sam zauważył - nie był przeciwny Adrianowowi, zastanawiał się jednak nad sensem uczestniczenia w pracach MKOl człowieka, który nie

\footnotetext{
27 Ibidem, s. 11.

${ }^{28}$ AMKOl, P04/003, Pismo Otto Mayera do J.S. Edströma z dnia 8 XII 1948 r., k. nlb.; AMKOl, P04/004, Pismo Otto Mayera do J.S. Edströma z dnia 15 II 1949 r., k. nlb.
} 
znał żadnego oficjalnego języka obowiązującego $\mathrm{w}$ tej organizacji ${ }^{29}$. Po raz kolejny sojusznikiem ZSRR w MKOl okazał się lord Burghley. Wyraźnie fascynował się organizacją sportu w ZSRR i uważał, że obecność Adrianowa w MKOl będzie bardzo ważna. Utrzymywał, że znał Adrianowa i nalegał na głosowanie za jego przyjęciem. Amerykanin Brundage publicznie stwierdził, że nie ma nic przeciwko kandydaturze Rosjanina. Sprzeciwiał się tylko zatrudnianiu i obecności na posiedzeniach MKOl tłumacza. Być może była to zawoalowana próba utracenia kandydata, który nie znał ani języka francuskiego, ani angielskiego. Nieoczekiwanie z pomoca Adrianowowi przyszedł pochodzacy z Belgii Rodolphe William Seeldrayers. Jego zdaniem w MKOl byli członkowie, którzy znali język rosyjski i mogli pomagać Rosjaninowi, dokładnie tłumacząc obrady. Pomysł ten poparł Francuz hrabia de Beaumont ${ }^{30}$.

Ostateczny wynik okazał się korzystny dla Adrianowa, ale nie było to głosowanie jednomyślne. 24 osoby głosowały „za”, 5 - „przeciw”, zaś 5 oddało czyste karty do głosowania ${ }^{31}$. Bardzo możliwe, że niektórym dotychczasowym członkom MKOl łatwiej było zaakceptować przyjęcie do organizacji ZSRR, aniżeli powitać $\mathrm{w}$ swoim gronie nieznającego oficjalnych języków MKOl Rosjanina. Być może niechęć niektórych członków MKOl okazała się większa, niż bariera polityczna pomiędzy Wschodem i Zachodem. Wszak członkowie MKOl w pewnym sensie tworzyli grupę elitarna. Byli wśród nich książęta, arystokraci i naukowcy. Z ich perspektywy Adrianow jawił się jako człowiek z zupełnie innego świata.

Przystapienie ZSRR do MKOl odmieniło tę organizację, lecz stwarzało też nowe problemy. Nieco ponad rok po wiedeńskiej sesji MKOl, w czerwcu 1952 r., a więc przed igrzyskami olimpijskimi w Helsinkach, prezydent MKOl w liście do Brundage'a, członka MKOl i swojego następcy, pisał: „Jestem pewien, że nasi rosyjscy przyjaciele będą dla nas przyczyną kłopotów na posiedzeniu MKOl przed Igrzyskami, a pozostałe kraje zza żelaznej kurtyny poprą ich"32. Rosjanie nie zadowolili się statusem jednego z wielu członków. W nieformalnej koalicji z pozostałymi państwami bloku radzieckiego podejmowali próby wzmocnienia swojej pozycji. W drugiej połowie lat sześćdziesiątych do tej „koalicji” zaczęły

${ }^{29}$ Oficjalnymi językami MKOl były francuski i angielski. Otto Mayer pisał do Edströma w liście z dnia 28 I 1952 r., że Rosjanie wystapili z propozycją uznania języka rosyjskiego za kolejny oficjalny język MKOl. Zob. AMKOl, P04/007, Pismo Otto Mayera do J.S. Edströma z dnia 28 I 1952 r., k. nlb. Zob. też: D. Miller, op. cit., s. 150; E.E. Redihan, The Olympics and the Cold War, 1948-1968. Sport as Battleground in the U.S.-Soviet Rivalry, Jefferson (NC) 2017, s. 97.

30 AMKOl, Admission membre pour l'U.R.S.S, w: Procès-Verbal. $45^{\text {me }}$ Session de Vienne 1951. 7-8 Mai 1951, s. 12 .

${ }^{31}$ Ibidem, s. 10 i n.

32 AMKOl, P04/007, Pismo S. Edströma do Avery Brundage'a z dnia 9 VI 1952 r., k. nlb. Tekst w oryginale brzmiał następująco: „I am sure that our Russian friends will cause us trouble at our IOC meeting before the Games and that the other countries inside the Iron Curtain will support them". 
dołączać państwa Trzeciego Świata ${ }^{33}$. Mimo to dopuszczenie ZSRR do udziału w ruchu olimpijskim stanowiło jedyne sensowne rozwiazanie, było też zgodne z ideałami barona Coubertina. Wszak sport i olimpizm miały „ustanawiać przyjacielskie związki między ludami”. Dotyczyło to także, a może przede wszystkim, „ludów” zwaśnionych, rozdzielonych. W powojennym, spolaryzowanym świecie to hasło było wyjątkowo aktualne. Decyzja o przyjęciu ZSRR do MKOl stwarzała więc szansę na autentyczny, nie tylko liczbowy, rozwój tej organizacji. Teoretycznie sprzyjała też nobilitacji olimpizmu i sportu, który miał być poważnym środkiem w drodze do osiągnięcia pokoju. Jednakże decyzja ta niosła też ryzyko. Bowiem sport, zamiast stanowić swoiste narzędzie służące osiagnięciu pokoju, mógł się stać polem walki politycznej między Wschodem i Zachodem. W powojennej historii MKOl łatwo wskazać wydarzenia, w których sport spełniał tę pozytywna, ale tė̇ i negatywną rolę.

Bez watpienia Rosjanie podeszli do sprawy uczestnictwa w ruchu olimpijskim z bardzo konkretnym i pragmatycznym celem. Wszak już w $1946 \mathrm{r}$. Andriej Żdanow, odpowiedzialny w ZSRR za sprawy kulturalne i ideologiczne, podczas przemówienia w KC KPZR ogłosił supremację kultury radzieckiej i nawoływał do ofensywy przeciw „dekadenckiemu” światu zachodniemu. Sport był jednym z obszarów tej ofensywy. Na początku, kiedy Rosjanie zabiegali o przystapienie do MKOl, nie mieli wielu atutów w swoich rękach ${ }^{34}$. Tymczasem, kiedy ten proces finalizowano, okazało się, że ich pozycja wcale nie była taka słaba. Wszak sesja, na której miała zapaść decyzja o przyjęciu ZSRR do MKOl, zorganizowana została na terenie znajdującym się pod kontrola ZSRR. Czy to nie był atut? Bardzo możliwe, że w uprzywilejowanej pozycji stawiała Rosjan prośba Sigfrida Edströma o pomoc w sprawie Karla Rittera von Halta. Niestety, nie znamy szczegółów całej historii związanej z uwolnieniem niemieckiego członka MKOl z obozu radzieckiego. Nie mam jednak wątpliwości, iż jeżeli Rosjanie zrobili „przysługę” Edströmowi, to wynagrodzenie za nią odebrali sobie z nawiązką. Ponadto wstępując do apolitycznej z założenia organizacji, Rosjanie świetnie rozegrali to politycznie. Wszak wszyscy członkowie MKOl, wywodzący się z krajów zależnych po II wojnie światowej od ZSRR, stawali się promotorami Kraju Rad w Komitecie. Ich opinie wypowiadane na forum tej organizacji były pozytywne dla Związku Radzieckiego. Oczywiście nie wiemy, jak głosowali, ale wobec korzystnych ostatecznych wyników nie miało to większego znaczenia. Nieistotne też było, czy ich demonstrowane poparcie dla Rosjan stanowiło wynik przyjętych ustaleń i instrukcji otrzymanych od władz politycznych własnych państw i ZSRR, czy też było motywowane strachem przed konsekwencjami braku okazywania tego poparcia dla Rosjan. Ten strach mógł wzbudzać obecny w czasie obrad,

\footnotetext{
33 A. Pasko, Sport wyczynowy w polityce państwa 1944-1989, Kraków 2012, s. 231.

34 J. Riordan, Sport In Soviet Society. Development of sport and physical education in Russia and the USSR, London-New York-Melbourne 1977, s. 363-364.
} 
a niebędący wówczas jeszcze członkiem MKOl, Adrianow. Do sukcesów Rosjan należał fakt, że został on zaproszony na salę.

Sigfrid Edström był prezydentem MKOl w wyjątkowo trudnych czasach. Kierował organizacja, która według założeń Coubertina miała być apolityczna. Postawa Szweda stanowiła, moim zdaniem, przykład zachowania prostolinijnego, pełnego dobrej woli. Edström działał zgodnie z ideałami, chciał powiększyć rodzinę olimpijską i udało mu się to wykonać. Problem MKOl i Edströma wynikał z tego, że prezydent był działaczem sportowym $\mathrm{w}$ skali międzynarodowej, ale nie potrafił być politykiem. W konfrontacji $\mathrm{z}$ de facto politykami radzieckimi poniósł porażkę. Zdał sobie z tego sprawę jeszcze przed przyjęciem ZSRR do MKOl, ale było zbyt późno, by zmienić wydarzenia. Jednocześnie wcale nie jestem pewien, czy chciał je zmienić.

\section{Streszczenie}

Działania ZSRR zmierzające do przystapienia do Międzynarodowego Komitetu Olimpijskiego spotkały się z akceptacja prezydenta tej organizacji, Johannesa Sigfrida Edströma. Okazało się, że prezydent MKOl prezentował niemal idealistyczne podejście do sprawy. Przynajmniej na początku tego procesu miał on nadzieję, że obecność ZSRR w organizacji zapobiegnie podziałowi świata sportu na Wschód i Zachód. Jego działania były zgodne z ideałami barona Pierre'a de Coubertina, jednak w konfrontacji z realistycznym podejściem Rosjan nie mogły doprowadzić do realizacji założonego celu. Edström był działaczem sportowym, nie miał jednak zmysłu polityka. Jego poważny błąd stanowiło zorganizowanie sesji MKOl, na której rozpatrywano wniosek ZSRR o przyjęcie do organizacji, w Wiedniu - mieście podzielonym wówczas na cztery sektory. Jeden z nich znajdował się pod okupacją radziecka. Miejsce obrad i poczucie zagrożenia przyjeżdżających na wiedeńską sesję stwarzało przewagę Rosjan, „zachęcało” tė̇ do głosowania korzystnego dla ZSRR. Innym błędem MKOl umacniającym pozycję ZSRR było zaproszenie do sali obrad kandydata na członka MKOl, Konstantina Adrianowa. Dzięki temu osobiście mógł on obserwować postawy członków MKOl z krajów znajdujących się w strefie wpływów ZSRR. Musieli więc oni pozytywnie wypowiadać się o ZSRR i Adrianowie. Ostatecznie głosowanie w sprawie przyjęcia ZSRR i członkostwa Adrianowa w MKOl zakończyło się pozytywnie. Okazało się jednak, że członkom MKOl łatwiej przyszło zaakceptować obecność ZSRR w tej organizacji, aniżeli przyjąć do swojego grona nieznającego oficjalnych języków MKOl Rosjanina. Moim zdaniem w konfrontacji z de facto politykami radzieckimi Edström poniósł porażkę. Kiedy zorientował się, że postawa ZSRR uniemożliwi mu realizację założonego celu, było już zbyt późno, nie mógł się wycofać. Jednak wcale nie jestem pewien, czy chciałby to zrobić.

\section{The inside story of the USSR's access to the International Olympic Committee}

The efforts of the USSR undertaken to join the International Olympic Committee met with the acceptance of the IOC's president Johannes Sigfrid Edström, who had almost idealistic attitude in this regard, in accordance with the ideals of Baron Pierre de Coubertin. At least in the early stage of the process, he hoped that the presence of the USSR in the IOC would prevent the split of the world of sports into the West and the East. In this, however, he was not right. Edström was a sport activist, deprived of a political sense, and his mistake was to have organised the accession session in Vienna, divided into four zones, one of which 
was the Soviet one. The place of the session and the sense of threat of the participants of the session not only gave the advantage to the Russians, but also influenced the vote in favour of the USSR. Another mistake made by the IOC that strengthened the position of the Russians was the invitation to the session the IOC member, Konstantin A, Adrianov. This made it possible for him to observe the attitude of individual members representing the countries of the Soviet bloc. Thus, they had no choice, and had to agree to the Soviet requests. Finally, the voting on the Soviet access to the IOC and Adrianov's membership was passed. But it turned out that it was easier for the IOC members to accept the presence of the Soviet Union itself than the membership of the Russian, who could not speak any of the official IOC languages. In my opinion, when confronted with Soviet politicians, Edström was defeated. When he noticed that the Soviet stance would make it impossible for him to realise his aim, it was already too late to withdraw. And I am not sure he would like to do it, anyway.

\section{Bibliografia}

Davies N., Europa. Rozprawa historyka z historiq, tłum. E. Tabakowska, Kraków 2001. Miller D., Historia igrzysk olimpijskich i MKOl. Od Aten do Pekinu 1894-2008, Poznań 2008. Pasko A., Baron Pierre de Coubertin - wizjoner i idealista, w: Ruch olimpijski $w$ teorii $i$ praktyce, red. J. Eider, Szczecin 2015, s. 7-20.

Pasko A., Spoteczno-polityczne aspekty sportu w ZSRR $i$ krajach bloku socjalistycznego do 1989 r., „Prace Naukowe Akademii im. Jana Długosza w Częstochowie. Kultura Fizyczna" 2011, z. 10.

Pasko A., Sport wyczynowy w polityce państwa 1944-1989, Kraków 2012.

Peppard V., Riordan J., Playing Politics. Soviet Sport Diplomacy to 1992, Greenwich-London 1993.

Redihan E.E., The Olympics and the Cold War, 1948-1968. Sport as Battleground in the U.S.-Soviet Rivalry, Jefferson (NC) 2017.

Riordan J., Sport In Soviet Society. Development of sport and physical education in Russia and the USSR, London-New York-Melbourne 1977.

Słoniewski M., Wpływ przewodniczacych Międzynarodowego Komitetu Olimpijskiego na przemiany w międzynarodowym ruchu olimpijskim po II wojnie światowej, „Prace Naukowe Akademii im. Jana Długosza w Częstochowie. Kultura Fizyczna” 2017, t. XVI, nr 1, s. $47-74$.

Wereszycki H., Historia Austrii, Wrocław-Warszawa-Kraków-Gdańsk-łódź 1986.

Biog r a m: Artur Pasko - dr hab., prof. UwB; pracownik naukowo-dydaktyczny Instytutu Historii i Nauk Politycznych UwB. Zainteresowania badawcze koncentrują się wokół problemów dotyczących związków sportu i polityki w Europie Środkowo-Wschodniej w XX w. E-mail: arturpasko@wp.pl. 